Original Research Paper

\title{
Effect of Different Rumen Undegraded Protein Level on Feed Consumption, Nutrient Digestion, Body Weight and Body Condition Score in Early Lactating Dairy Cattle
}

\author{
${ }^{1}$ Budi Prasetyo Widyobroto, ${ }^{1}$ Rochijan, ${ }^{1}$ Fajar Satrio Pradana and ${ }^{2}$ Lies Mira Yusiati \\ ${ }^{I}$ Department of Animal Production, Faculty of Animal Science, \\ Universitas Gadjah Mada, Jl. Fauna No. 3, Bulaksumur, Yogyakarta 55281 - Indonesia \\ ${ }^{2}$ Department of Animal Nutrition and Feed Science, Faculty of Animal Science, \\ Universitas Gadjah Mada, Jl. Fauna No. 3, Bulaksumur, Yogyakarta 55281 - Indonesia
}

Article history

Received: 08-02-2018

Revised: $16-04-2018$

Accepted: 12-05-2018

Corresponding Author:

Rochijan

Department of Animal

Production, Faculty of Animal

Science, Universitas Gadjah

Mada, Jl. Fauna No. 3,

Bulaksumur, Yogyakarta 55281

- Indonesia

Email: rochijan@mail.ugm.ac.id

\begin{abstract}
The objective of this study was to determine effect of different rumen undegraded protein level on feed consumption, nutrient digestion, body weight and body condition score in early lactating dairy cattle. Ten Friesian Holstein cows were divided into two groups (five animals were used as control and another group as treatment object). Diets were forages and concentrates with ratio of 60:40, DM basis. The cows feed after parturition until 100 days of lactation. The control group concentrate diets containing Crude Protein (CP) $18.55 \%$, Total Digestible Nutrient (TDN) $56.94 \%$ and Rumen Undegraded Protein (RUP) $5.10 \mathrm{CP} \%$, while the treatment group concentrate diets containing Crude Protein (CP) $18.83 \%$, Total Digestible Nutrient (TDN) 58,91\% and Rumen Undegraded Protein (RUP) $6.17 \mathrm{CP} \%$. Drinking water was given by ad libitum. The comparison results between the two conditions (control and treatment) were tested using independent t-test analysis. Results indicated that nutrient intake and digestion (dry matter, organic matter, crude protein, crude fibre and ether extract), body weight and body condition score were not significant. The conclusion is supplementation with different rumen undegraded protein level on early lactating dairy cattle could not increase feed consumption, nutrient digestion, body weight and body condition score.
\end{abstract}

Keywords: Rumen Undegraded Protein, Feed Consumption and Nutrient Digestion, Body Weight, Body Condition Score, Dairy Cattle

\section{Introduction}

The first lactation period which is the first quarter of lactation, also called the first 100 days of lactation, were critical period on dairy cow performances for those with high milk production. The high milk production dairy cow needs an adequate nutrient, especially protein. Microbial protein synthesized in the rumen supplies amino acids to the ruminant in sufficient quantities to support a moderate level of productivity (McAllister et al., 1992). Drackley et al. (2001), added that the contribution of Amino Acid (AA) to gluconeogenesis has been considered important during early lactation in the dairy cow, but supportive evidence has come from observations either in vivo or in vitro. Doepel et al. (2009), also added that the other important demand for AA is to support milk protein synthesis and this requirement increases greatly at the onset of lactation.
Therefore, despite an increased supply of MP through increased DM Intake (DMI) and rations formulated for lactation, these 2 demands create a negative protein balance for cows in early lactation. Invariably, the early lactating cow faces a glucose and amino acid deficiency (Phillips et al., 2003). NRC (2001) also explains that to ameliorate this nutrient deficiency, body fat and protein reserves are mobilized to support the energy requirements for high milk production in early lactation. Although body fat deposits are recognized as the major source of energy reserves, the catabolism of both body fat and protein contribute to nutrient requirements at early lactation.

Body protein mobilization is driven by the high demand need to supply amino acids for hepatic gluconeogenesis and for milk protein synthesis during early lactation. Propionate or propionic acid is the major precursor for gluconeogenesis (Drackley et al., 2001). However, limited feed intake during early lactation 
limits ruminal propionate supply to the liver, raising the requirement for alternative gluconeogenic precursors. Although skeletal muscle is the primary labile source of amino acids and only a few studies have investigated protein metabolism in this tissue during lactation (Komaragiri et al., 1998; Phillips et al., 2003; Chibisa et al., 2008). Skeletal muscle protein mass has been shown to decrease in early lactating dairy cows (Komaragiri et al., 1998; Phillips et al., 2003). Although the mobilization of protein reserves is necessary to augment the inadequate dietary supply of energy and protein, excessive mobilization can lead to an increased incidence of metabolic disorders and animal health, poor reproductive and lactation performance (Overton et al., 1998).

However, at high levels of production, the supply amino acid from microbial protein is often inadequate for optimal productivity (Chalupa, 1975), different from the lactation dairy cow group with low to moderate production that is always sufficient. Efficiency of ruminant production may also be improved by increasing the supply of starch or protein to the small intestine (Owens et al., 1986), with methods of energy and protein supplementation or protection of feed ingredients that have high biological value. Soybean meal by treatment with formaldehyde would appear to be a potential method of decreasing rumen degradation of high quality protein and allowing more dietary protein by-pass the rumen to abomasum and lower digestive tract. Widyobroto et al. $(1995 ; 2010)$ added that protein protection (by-pass) by formaldehyde addition or heating could increase the undegraded protein fraction of 50 to $80 \%$ and did not decrease its digestibility in the intestinum. Rumen Undegraded Protein (RUP) supplement based on the requirement of rumen microbes on nitrogen precursor has to be calculated to improve nutrient efficiency and milk production; and an increase in RUP level in the ration will increase the use of nutrients by dairy cows, although it also depends on the energy intake (Widyobroto et al., 2001). The objective of this study was to determine effect of different rumen undegraded protein level on feed consumption, nutrient digestion, body weight and body condition score in early lactating dairy cattle.

\section{Materials and Methods}

\section{Animal and Material Study}

This study was conducted in dairy cow units farm Department of Agriculture Yogyakarta Province, Indonesia. Analysis of feed and faeces samples was conducted in Laboratory of Dairy Science and Milk Industry and Laboratory of Nutritional Biochemistry, Faculty of Animal Science Universitas Gadjah Mada.

This study used 10 early lactation Friesian Holstein cows, after parturition with an average live body weight of 400 to $500 \mathrm{~kg}$, age cows 3.5 to 5 years, lactating periods $2^{\text {nd }}$ to $3^{\text {rd }}$, average milk production in foregoing lactation was $10 \mathrm{~L} /$ head/day and cows in permanent enclosure models stanchion barn with cement floors and rubber mat. The diets were forages and concentrate especially formulated using the same materials (Table 1). Forages used is Pennisetum purpuphoides and material commercial concentrate is Copra meal, CGM, Pollard, Palm kernel meal, Kapok seed meal, Coffee husk, Corn tumpi, Cassava waste, Molasses, G-Pro and Mineral mix. The diets ratio for forage and concentrates were 60:40, DM basis. The cows were fed 100 days during lactation. Drinking water was given by ad libitum.

\section{Feed and Faecal Sample Collection and Preparation}

The diets ingredients or sample were composited for each collection period and dried in a $55^{\circ} \mathrm{C}$ forced-air oven. Then analyzed to determine the content Dry Matter (DM), Organic Matter (OM), Crude Protein (CP), Crude Fibre (CF) and Ether Extract (EE). Faeces were sampled daily during each collection period (14 days). Faeces sample were composited for each collection period and analyzed for DM, OM, CP, CF and EE. The dried feed and faeces samples were used for chemical or nutrient analysis.

\section{Body Weight and Body Condition Score}

Body Weight (BW) and Body Condition Score (BCS) were calculated as the average of measurements performed of first and last week, before morning meal and after am milking during the study. The assessment of BCS was determined by observed cows on the vertebral column (back), waist, hunch, roof of tail, hip bone, waist horn and ribs as point. Body condition score for dairy cows use a scale 1 to 5 , with scale 1: being emaciated, scale 2: Thin, scale 3: Averages, scale 4: Fats and scale 5: Obese (Wildman et al., 1982; Rochijan, 2014). The BCS of each animal was evaluated by the same person and was done by some people to reduce the subjectivity.

\section{Data Analysis}

The data on feed consumption, nutrient digestion, body weight and body condition score were tested using independent samples t-test analysis at $\mathrm{P}<0.05$, with Statistical Program for Social Science (SPSS) version 16.0.

\section{Results and Discussion}

\section{Nutrient Composition of Feed Ingredients Concentrates}

Nutrient composition of concentrates feed presented in Table 1, consists of: Concentrate and soybean meal$\mathrm{HCHO}$; and forages is Pennisetum purpuphoides. The control group concentrate containing crude protein (CP) 18.55\%, Total Digestible Nutrient (TDN) 56,94\% and Rumen Undegraded Protein (RUP) $5.10 \mathrm{CP} \%$, while the treatment group concentrate containing Crude Protein (CP) $18.83 \%$, Total Digestible Nutrient (TDN) 58,91\% and Rumen Undegraded Protein (RUP) 6.17 CP\%. 


\section{Feed Consumption and Nutrient Digestion}

The average feed and nutrient consumption of dairy cows during the study was presented in Table 2 . The mean of feed and nutrient consumption collected from early lactating dairy cows did not differ among diets in both groups. This was similar to the study of Widyobroto et al. (2010; Widyobroto, 2013; Rochijan, 2014) which found that the increase of RUP level in the ration was not influenced by Dry Matter Intake (DMI) in ration. Organic Matter Intake (OMI) can be improved with decreasing RUP level in the current study. The high protein intake was caused by concentrates in ration has high protein content.

The DMI has special importance to meet nutrient requirement of early lactating dairy cows to maintain their health and productivity (production and reproduction). Dietary Fibre Content (CF) in ration had no influence on $\mathrm{DM}$ and $\mathrm{OM}$ intake in this trial. Commonly, an increase in dietary CF and Crude Protein (CP) can be achieved by increasing the level of concentrates. Therefore, the results of the current study are comparable with those obtained by CantalapiedraHijar et al. (2009; Ramos et al., 2009), who found no effect of dietary concentrate : forage ratios (30:70 and 70:30) on OMI in both goats and sheep fed above maintenance. However, Allen (2000) noted that no effect of CF ranging from 25 to $40 \%$ was found on DMI in dairy cows, although feed intake generally decreases with increasing $\mathrm{CF}$. Protein and energy intake from control and treatment rations were more than enough to fulfill the need of maintenance and productivity (production and reproduction) and if the protein intake in the rations is excessive then it will be a waste for the environment derived from urine and faecal. This wasn't similar to the results of study by Encinias et al. (2005), that there was no difference in DMI on lactating dairy cows fed Brome grass hay $(9.6 \% \mathrm{CP})$ which is undegraded protein supplementation.

The average nutrient digestion of dairy cows was presented in Table 3. The mean nutrient digestion collected from early lactation dairy cows did not differ in both groups on DM, OM, CP, CF and EE digestion. Feed protection that has high biological value with formaldehyde treatment tended to have a greater effect on digestibility of cereal protein than that of cereal starch (Huhtanen et al., 1985; Morgan et al., 1989). Nevertheless, a reduction in the concentration of Volatile Fatty Acids (VFA) associated with microbial amino acid metabolism suggested that protein in the formaldehyde-treated feeds was more resistant to microbial degradation. With increase resistance to microbial digestion, the amount of NPN reaching the duodenum will to be increased with formaldehyde-treated feed supplementation. Higher amount of NPN at the duodenum with these diets will to increase amounts of individual amino acids at the duodenum as compared to control diet. However, with the exception of glutamine, formaldehyde treatment did not alter the amino acid compositions of duodenal digest. A decrease in the susceptibility of dietary protein to microbial attack usually reduces the quantity of microbial $\mathrm{N}$ reaching the small intestine and depresses the efficiency of microbial protein synthesis (McCarthy et al., 1989; Hussein et al., 1991). Bunnakit and Khampa (2011) reported that DMI and OM digestibility in Thai Native $\mathrm{x}$ Brahman cattle increased linearly while the level of RUP increased. In another study, the use of protein source with lower rumen degradability promotes an increase in the flow of nutrients and changes in the digestive parameters of the omasum, but compromise the production or microbial efficiency in dairy goats (Felisberto et al., 2011).

Table 1: Feed concentrate and nutrient compositions of experimental diet

\begin{tabular}{|c|c|c|c|}
\hline \multirow[b]{2}{*}{ Feed concentrates } & & \multicolumn{2}{|l|}{ Group } \\
\hline & & Control & Treatment \\
\hline \multirow[t]{3}{*}{ Ingredients (\%DM) } & Commercial concentrate & 100.00 & 91.00 \\
\hline & Soybean meal-HCHO & - & 9.00 \\
\hline & Total & 100.00 & 100.00 \\
\hline \multirow[t]{8}{*}{ Analyzed compositions } & Dry matter $(\%)$ & 88.24 & 89.06 \\
\hline & Organic matter $(\%)$ & 87.93 & 88.37 \\
\hline & Crude protein $(\%)$ & 18.55 & 18.83 \\
\hline & Crude fibre $(\%)$ & 16.81 & 16.06 \\
\hline & Ether extract (\%) & 5.10 & 4.70 \\
\hline & RUP $(\mathrm{CP} \%)$ & 5.10 & 6.17 \\
\hline & RDP (CP\%) & 11.79 & 11.46 \\
\hline & TDN (\%) & 56.94 & 58.91 \\
\hline
\end{tabular}

RUP = Rumen Undegraded Protein; RDP = Rumen Degraded Protein; TDN = Total Digestible Nutrient 
Table 2: Feed and nutrient consumption of dairy cows receiving control and treatment

\begin{tabular}{|c|c|c|c|c|c|c|}
\hline \multirow[b]{3}{*}{ Nutrients consumption } & \multicolumn{6}{|c|}{ Ration (kg DM/head/day) } \\
\hline & \multicolumn{2}{|l|}{ Forages } & \multicolumn{2}{|c|}{ Concentrate } & \multicolumn{2}{|c|}{ Total consumption } \\
\hline & Control & Treatment & Control & Treatment & Control & Treatment \\
\hline Dry matter ${ }^{\text {ns }}$ & 7.15 & 7.09 & 4.49 & 4.45 & 11.64 & 11.54 \\
\hline Organic matter $^{\text {ns }}$ & 6.21 & 6.16 & 3.95 & 3.93 & 10.15 & 10.10 \\
\hline Crude protein ${ }^{\mathrm{ns}}$ & 0.67 & 0.66 & 0.83 & 0.84 & 1.50 & 1.50 \\
\hline Crude fibre $^{\text {ns }}$ & 2.35 & 2.34 & 0.75 & 0.71 & 3.10 & 3.05 \\
\hline Ether extract $^{\text {ns }}$ & 0.20 & 0.21 & 0.13 & 0.10 & 0.33 & 0.31 \\
\hline
\end{tabular}

ns: Non significant $(\mathrm{P}>0.05)$

Table 3: Nutrient digestion of early lactation dairy cows receiving control and treatment

\begin{tabular}{llr}
\hline & Group ration (\%) & \\
Nutrient digestion & - & Treatment \\
\hline Dry matter $^{\text {ns }}$ & Control & $60.23 \pm 1.42$ \\
Organic matter $^{\text {ns }}$ & $55.43 \pm 2.73$ & $67.15 \pm 1.51$ \\
Crude protein $^{\text {ns }}$ & $66.29 \pm 2.65$ & $73.99 \pm 1.77$ \\
Crude fibre $^{\text {ss }}$ & $74.32 \pm 1.52$ & $50.93 \pm 1.79$ \\
Ether extract $^{\text {ns }}$ & $41.35 \pm 3.79$ & $62.76 \pm 0.95$ \\
\hline
\end{tabular}

ns: Non significant $(\mathrm{P}>0.05)$

Table 4: Average of body weight and body condition score in dairy cows

\begin{tabular}{llc}
\hline & Group & Treatment \\
Parameters & Control & \\
\hline Body Weight $(\mathrm{BW}):$ & & \\
First week of experiment $^{\mathrm{ns}}$ & $450.83 \pm 85.29$ & $430.67 \pm 46.54$ \\
Last week of experiment $^{\mathrm{ns}}$ & $469.67 \pm 76.14$ & $454.33 \pm 37.98$ \\
Average of BW $^{\mathrm{ns}}$ & $449.06 \pm 78.32$ & $431.50 \pm 39.20$ \\
Body Condition Score $(\mathrm{BCS}):^{\text {First week of experiment }}{ }^{\mathrm{ns}}$ & $3.17 \pm 0.26$ & $3.29 \pm 0.19$ \\
Last week of experiment $^{\mathrm{ns}}$ & $3.17 \pm 0.62$ & $3.38 \pm 0.31$ \\
Average of BCS $^{\mathrm{ns}}$ & $3.09 \pm 0.26$ & $3.25 \pm 0.22$ \\
\hline
\end{tabular}

ns: Non significant $(\mathrm{P}>0.05)$

\section{Body Weight and Body Condition Score}

The mean of Body Weight (BW) and Body Condition Score (BCS) on early lactating dairy cattle did not differ in both groups $(\mathrm{P}>0.05)$. The average $\mathrm{BW}$ and $\mathrm{BCS}$ of dairy cows during the study were presented in Table 4 . An indicator of energy balance status is BCS. If dairy cows are too fat at calving and diets are not provided ad libitum or not well formulated, cows will lose more body condition. This change in Body Condition (BCS) well correlates with cumulative Negative Energy Balance (NEB) and lipid mobilization stored in the body (Domecq et al., 1997a; 1997b), full stop, BCS might be used as indicator of energy balance during early lactation (DeVries and Veerkamp, 2000). Taylor and Field (2004) reported that after parturition, cows hardly provide adequate nutrient for milk production due to limited feed consumption, so the lipid was mobilized to fulfill the needs of nutrient. Van Knegsel et al. (2007) added that glucogenic diets in comparison with lipogenic diets, resulted in deposition of energy in the body. These findings show that glucogenic nutrients such as RUP supplements in the study, lead to improve BCS due to decreased body tissue mobilization by increasing DMI. The replacement of RDP with RUP supplements in lactating cows, improved energy balance and led to $9 \%$ increases in amount of NEl consuming (Santos et al., 1999).

Dry Matter Intake has special importance to meet nutrient requirement of early lactating dairy cows to maintain their health and productivity (production and reproduction). According to Nathalie et al. (2004), low DMI and deficiency in nutrient supply (especially protein and amino acids), could led to immunosuppression and incidence of metabolic disorders consisted of decline in the value of BCS, ketosis, fatty liver and displaced abomasum (Drackley et al., 2001; Duffield et al., 2009). Thus, diets that have higher levels of CP and RUP are effective in maintaining cows productivity (production and reproduction) and BCS value (NRC, 2001). Early lactating dairy cows in first days of lactation period (especially immediately after parturition) will lose appetite, because of increased level of estrogen 
in blood plasma (Ingvartsen, 2006). If the feed intake provided is insufficient, either in terms of quantity or quality, then the cow will utilize the nutrients available within its body by mobilizing the stored energy within their body tissues. As the consequence of this mobilization, the cow will lose so much BW and decline in BCS value, which will affect the cow production and reproduction performance postpartum (Mundingsari, 2006; Rochijan et al., 2014). NRC (2001) recommended high concentration of $\mathrm{CP}$ for high levels of milk production, therefore, because of low DMI in early lactating dairy cows, this amount of $\mathrm{CP}$ must meet in the form of high concentrate of RDP and RUP in diets (Khorasani et al., 1996).

Ipharraguerre and Clark (2005) reported that decreasing DMI in early postpartum period causes declining in passage rate and consequently protein degradability in the rumen increases, thus will decrease ruminal outflow of non-ammonia nitrogen, nonammonia non microbial nitrogen and follow that entering of essential amino acids into small intestine, which has an impact on the decline of BCS. However, using feed ingredients containing a rich source of leucine in diets of early lactating dairy cows could be an effective factor in maintaining protein reserves of body and consequently improve BCS changes. Likewise, branched chain amino acids have several roles in whole body metabolism and could influence insulin secretion. Amino acids could influence secretion of metabolic hormones, especially prolactin and insulin (Lal and Chugh, 1995; Gamsworthy et al., 2008) and leucine directly stimulates mRNA level of insulin in pancreas cells (Docherty and Clark, 1994). Increasing dietary CP from calving day to 150 DIM had led to increased energy consumption, BW and BCS of dairy cows had numerically increased that were in agreement with the findings (Law et al., 2009).

\section{Conclusion}

The conclusion is supplementation with different rumen undegraded protein level on early lactating dairy cattle could not increase feed consumption, nutrient digestion, body weight and body condition score.

\section{Acknowledgment}

We thanks to Head of dairy cow units farm Department of Agriculture Yogyakarta Province, Indonesia for providing experimental facilities, materials and technical support throughout this study.

\section{Author's Contribution}

Budi Prasetyo Widyobroto: Designed the experiments, analyzed the data and contributed to the writing of the manuscript.
Rochijan: Designed and performed the experiments, analyzed the data and contributed to the writing of the manuscript.

Fajar Satrio Pradana: Performed the experiments, analyzed the data and contributed to the writing of the manuscript.

Lies Mira Yusiati: Performed the experiments and analyzed the data.

\section{Ethics}

All the authors have approved the manuscript and agree with submission to the esteemed journal. There are no conflicts of interest to be declared.

\section{References}

Allen, M.S., 2000. Effects of diet on short-term regulation of feed intake by lactating dairy cattle. J. Dairy Sci., 83: 1598-1624.

DOI: $10.3168 /$ jds.S0022-0302(00)75030-2

Bunnakit, K. and S. Khampa, 2011. Effect of rumen undegradable protein levels on performance of Thai native x Brahman beef cattle. J. Nutr. Pak., 10: 1163-1167. DOI: 10.3923/pjn.2011.1163.1167

Cantalapiedra-Hijar, G., D.R. Yanez-Ruiz, A.I. MartinGarcia and E. Molina-Alcaide, 2009. Effects of forage: Concentrate ratio and forage type on apparent digestibility, ruminal fermentation and microbial growth in goats. J. Anim. Sci., 87: 622-631. DOI: $10.2527 /$ jas.2008-1142

Chalupa, W., 1975. Rumen bypass and protection of proteins and amino acids. J. Dairy Sci., 58: 1198-1218. DOI: 10.3168/jds.S0022-0302(75)84697-2

Chibisa, G.E., G.N. Gozho, A.G. Van Kessel, A.A. Olkowski and T. Mutsvangwa, 2008. Effects of peripartum propylene glycol supplementation on nitrogen metabolism, body composition and gene expression for the major protein degradation pathways in skeletal muscle in dairy cows. J. Dairy Sci., 91: 3512-3527. DOI: 10.3168/jds.2007-0920

DeVries, M.J. and R.F. Veerkamp, 2000. Energy balance of dairy cattle in relation to milk production variables and fertility. J. Dairy Sci., 83: 62-69. DOI: $10.3168 /$ jds.S0022-0302(00)74856-9

Docherty, K. and A.R. Clark, 1994. Nutrient regulation of insulin gene expression. FASEB J., 8: 20-27. DOI: 10.1096/fasebj.8.1.8299887

Doepel, L., G.E. Lobley, J.F. Bernier, P. Dubreuil and H. Lapierre, 2009. Differences in splanchnic metabolism between late gestation and early lactation dairy cows. J. Dairy Sci., 92: 3233-3243. DOI: $10.3168 /$ jds.2008-1595 
Domecq, J.J., A.L. Skidmore, J.W. Lloyd and J.B. Kaneene, 1997a. Relationship between body condition scores and conception at first artificial insemination in a large dairy herd of high yielding Holstein cows. J. Dairy Sci., 80:113-120. DOI: 10.3168/jds.S0022-0302(97)75918-6

Domecq, J.J., A.L. Skidmore, J.W. Lloyd and J.B. Kaneene, 1997b. Relationship between body condition scores and milk yield in a large dairy herd of high yielding Holstein cows. J. Dairy Sci., 80: 101-112. DOI: 10.3168/jds.S0022-0302(97)75918-6

Drackley, J.K., T.R. Overton and G.N. Douglas, 2001. Adaptations of glucose and long-chain fatty acid metabolism in liver of dairy cows during the periparturient period. J. Dairy Sci., 84: 100-112. DOI: 10.3168/jds.S0022-0302(01)70204-4

Duffield, T.F., K.D. Lissemore, B.W. McBride and K.E. Leslie, 2009. Impact of hyperketonemia in early lactation dairy cows on health and production. J. Dairy Sci., 92: 571-580. DOI: 10.3168/jds.2008-1507

Encinias, A.M., G.P. Lardy, J.L. Leupp, H.B. Encinias and L.P. Reynolds et al., 2005. Efficacy of using a combination of rendered protein products as an undegradable intake protein supplement for lactating, winter-calving, beef cows fed bromegrass hay. J. Anim. Sci., 83: 187-195. DOI: $10.2527 / 2005.831187 \mathrm{x}$

Felisberto, N.R.O., M.T. Rodrigues, M.A.D. Bomfim, R.S. Matos and A.G.P.C. Cordeiro et al., 2011. Effects of different sources of protein on digestive characteristics, microbial, efficiency and nutrient flow in dairy goats. R. Bras. Zootec., 40: 2228-2234. DOI: 10.1590/S1516-35982011001000024

Gamsworthy, P.C., A. Lock, G.E. Mann, K.D. Sinclair and R. Webb, 2008. Nutrition, metabolism and fertility in dairy cows: 1 . Dietary energy source and ovarian function. J. Dairy Sci., 91: 3814-3823. DOI: $10.3168 /$ jds.2008-1031

Huhtanen, P., E. Poutiainen and T. Mikkols, 1985. The Effect of Supplementation of Silage with rapeseed meal or Gasol-treated barley on the performance of growing cattle. J. Agric. Sci. Finland, 57: 57-84.

Hussein, H.S., R.M. Jordan and J.D. Stern, 1991. Ruminal protein metabolism and intestinal amino acid utilization as affected by dietary protein and carbohydrate sources in sheep. J. Anim. Sci. 69: 2134-2146. DOI: 10.2527/1991.6952134x

Ingvartsen, K.L., 2006. Feeding and management related diseases in the transition cow physiological adaptations around calving and strategies to reduce feeding related diseases. Anim. Feed Sci. Tech., 126: $175-213$.

DOI: $10.1016 /$ j.anifeedsci.2005.08.003

Ipharraguerre, I.R. and J.H. Clark, 2005. Impacts of the source and amount of crude protein on the intestinal supply of nitrogen fractions and performance of dairy cows. J. Dairy Sci., 88: 22-37.

DOI: 10.3168/jds.S0022-0302(05)73134-9
Khorasani, G.R., G.D.E. Boer and J. Kennelly, 1996. Response of early lactation cows to ruminally undegradable protein in the diet. J. Dairy Sci., 79: 446-453. DOI: 10.3168/jds.S0022-0302(96)76384-1

Komaragiri, M.V.S., D.P. Casper and R.A. Erdman, 1998. Factors affecting body tissue mobilization in early lactation dairy cows. II. Effect of dietary fat on mobilization of body fat and protein. J. Dairy Sci., 81: 169-175.

DOI: $10.3168 /$ jds.S0022-0302(98)75564-X

Lal, H. and K. Chugh, 1995. Metabolic and regulatory effect of branched chain amino acid supplementation. Nutr. Res., 15: 1717-1733. DOI: 10.1016/0271-5317(95)02042-2

Law, R.A. F.J. Young, D.C. Patterson, D.J. Kilpatrick and A.R.G. Wylie et al., 2009. Erratum to "effect of dietary protein content on animal production and blood metabolites of dairy cows during lactation". J. Dairy Sci., 92: 1001-1012. DOI: 10.3168/jds.2008-1155

McAllister, T.A., L.M. Rode, K.J. Cheng and J.G. Buchanan-Smith, 1992. Effect of formaldehydetreated barley or escape protein on the ruminal environment and digestion in steers. Can. J. Anim. Sci., 72: 317-328. DOI: 10.4141/cjas92-038

McCarthy, J.R.D., T.H. Klusmeyer, J.L. Vicini, J.H. Clark and D.R. Nelson, 1989. Effects of source of protein and carbohydrate on ruminal fermentation and passage of nutrients to the small intestine of lactating cows. J. Dairy Sci., 72: 2002-2016. DOI: $10.3168 / j d s . S 0022-0302(89) 79324-3$

Morgan, D.J., R.F. Cody and P.K. Upton, 1989. Cereal digestion in the ruminant: 2. Effect of formaldehyde treatment of barley upon rumen degradability and nutrient flow to the intestine of sheep. Irish J. Agric. Res., 28: 43-48.

Mundingsari, R.D., 2006. The effect of substitution energy and protein concentrates supplement on milk production and some parameters reproduction of early lactation Friesian Holstein Crossbred cows. $\mathrm{PhD}$. Thesis, Universitas Gadjah Mada, Indonesia.

Nathalie, L.F., M. Delphine and O. Christiane, 2004. Modifications of protein and amino acid metabolism during inflammation and immune system activation. Livestock Product. Sci., 87: 37-45. DOI: $10.1016 /$ j.livprodsci.2003.09.005

NRC, 2001. Nutrient Requirements of Dairy Cattle. 7th Edn., National Academy Press, Washington, DC.

Overton, T.R., J.K. Drackley, G.N. Douglas, L.S. Emmert and J.H. Clark, 1998. Hepatic gluconeogenesis and whole body protein metabolism of periparturient dairy cows as affected by source of energy and intake of the prepartum diet. J. Dairy Sci., 81: 295-295.

Owens, F.N., R.A. Zinn and Y.K. Kim, 1986. Limits to starch digestion in the ruminant small intestine. J. Anim. Sci., 63: 1634-1648. DOI: $10.2527 /$ jas $1986.6351634 x$ 
Phillips, G.J., T.L. Citron, J.S. Sage, K.A. Cummins and M.J. Cecava et al., 2003. Adaptations in body muscle and fat in transition dairy cattle fed differing amounts of protein and methionine hydroxy analog. J. Dairy Sci., 86: 3634-3647. DOI: $10.3168 /$ jds.S0022-0302(03)73969-1

Ramos, S., M.L. Tejido, M.E. Martinez, M.J. Ranilla and M.D. Carro, 2009. Microbial protein synthesis, ruminal digestion, microbial populations and nitrogen balance in sheep fed diets varying in forage-to-concentrate ratio and type of forage. J. Anim. Sci., 87: 2924-2934. DOI: $10.2527 /$ jas.2009-1938

Rochijan, 2014. Effect of supplementation rumen undegraded protein on production and reproduction dairy cows. M.Sc. Thesis, Universitas Gadjah Mada, Indonesia.

Rochijan, B. Rustamadji and Kustono, 2014. Milk production and composition of friesian holstein crossbred cows with $3 \%$ outdate milk powder supplementation in early lactation period. Proceedings of Seminar Nasional Sinergi Pangan, Pakan, dan Energi Terbarukan, Oct. 21-23, Yogyakarta, pp: 325-331.

Santos, J.E.P., J.T. Huber, C.B. Theurer, L.G. Nussio and M. Tarazon et al., 1999. Response of lactating dairy cows to steam-flaked sorghum, steam-flaked corn, or steam-rolled corn and protein sources of differing degradability. J. Dairy Sci., 82: 728-737. DOI: $10.3168 /$ jds.S0022-0302(99)75290-2

Taylor, R.E and T.G. Field, 2004. Scientific Farm Animal Production: An Introduction to Animal Science. 8th Edn., Perason Prentice Hall, Upper Saddle River, New Jersey (US), ISBN-10: 013048170X, pp: 764.
Van Knegsel, A.T.M., H. van Den-Brand, J. Dijkstra, W.M. van Straalen and M.J.W. Heetkamp et al., 2007. Dietary energy source in dairy cows in early lactation: Energy partitioning and milk composition. J. Dairy Sci., 90: 1467-1476. DOI: $10.3168 /$ jds.S0022-0302(07)71632-6

Widyobroto, B.P., 2013. Implementasi Sistem Penyusunan Ransum Sapi Perah di Indonesia Berdasarkan Protein Tercerna di Intestinum [Implemented dairy cattle ration formulation based on intestine protein degradation in Indonesia]. Faculty of Animal Science, Universitas Gadjah Mada, Yogyakarta.

Widyobroto, B.P., S. Padmowijoto, R. Utomo and M. Soejono, 1995. In sacco degradation of eight tropical forages. Ann. Zootch., 44: 194-194.

DOI: 10.1051/animres:199505162

Widyobroto, B.P., S.P.S. Budhi and A. Agus, 2010. Effect of protein undegraded supplementation on production and composition of milk in dairy cows. J. Indonesian Trop. Anim. Agric., 35: 27-33.

DOI: $10.14710 /$ jitaa.35.1.27-33

Widyobroto, B.P., S.P.S. Budhi and A. Agus. 2001. Effect of undegraded levels on rumen fermentation parameters kinetic and microbial protein synthesis in Friesian Holstein Grade Cows. J. Indonesian Trop. Anim. Agric.

Wildman, E.E., G.M. Jones, P.E. Wagner and R.L. Bowman, 1982. A dairy cow body condition scoring system and its relationship to selected production characteristics. J. Dairy Sci., 65: 495-501.

DOI: $10.3168 /$ jds.S0022-0302(82)82223-6 